\title{
KURTA HÍVÓSZAVAK EGY ÁTMENETI HELYZETBEN: A CSŐD, A MINŐSÉG, A SZAK ÉS AZ ÁR
}

\section{HUNYADY GYÖRGY}

\author{
az MTA rendes tagja \\ hunyady.gyorgy@ppk.elte.hu
}

Nem vitás: miután épp hogy megtörtént a pedagógusképzés beiktatása a bolognairendszerbe, hirtelen felcsapott a belső ellenkezés és a külső ellenzés. Kérdésessé vált a „magyar Bologna” általában és a megreformált tanárképzés különösen. A hosszú vitákban kiküzdött szabályozás és a tanárszak bevezetése az átmenetiség állapotában lebeg, nem a megnyugvás és az aprómunka ideje jött el, hanem a vélt és valódi hibák számbavétele és a fejlesztés alapkérdéseinek megnyitása. Nem kell pszichológusnak lenni ahhoz, hogy lássuk, mindez a politikai váltás atmoszférájában történik, amelyben a tárgyszerü és kiegyensúlyozott mérlegelés esélye csökken, ám amiben felfokozott a hangulati tényezők szerepe, az elemzést könnyüszerrel kiválthatja a hatáskeltő kommunikáció. Ebben a közéleti sodrásban a problémák komplexitása eltünik, hívószavak mozgatnak meg egyszerü gondolati sémákat és hívnak elő érzelemvezérelt, rövidzárlatosan gyors értékeléseket. Ilyen hatásokkal számolva, ezek ellenében fogalmazom meg hozzászólásomat négy kurta hívószóhoz rendelve.

A csőd. Mintegy magától értetődően hangzik el, akár a legtekintélyesebb akadémiai fórumokon és azok képviseletében, hogy a bolognai-rendszerü tanárképzés csődbe jutott. Ennek a kimondott, vagy a megfogalmazás mélyén rejlő állításnak valójában nincs alapja, ha csak az nem, hogy e fórumok és képviselők csődről beszélnek, ami persze önmagában elég kedvszegö és romboló hatású. Az azonban a súlyos szó mélyebb értelmében nem minősülhet csődnek, hogy azok, akiknek az átfogó reformmal kapcsolatban kezdetektől fenntartásaik voltak, akik rossz szemmel nézték kidolgozásának folyamatát, illetve bevezetésében kedvetlenül és enerváltan vettek részt, most - egy megváltozott konstellációban - kimondják negatív véleményüket. Nincs, mert valójában nem lehet, gyakorlati tapasztalat a bolognairendszer müködéséről a tanárképzésben, hiszen hallgatói csak most léptek be, végzettjei nincsenek, a teljeskörü szakmai részvétellel kidolgozott programjait csak első ízben tesszük próbára, koncepcionális alapelveinek müködéséről és közoktatási beválásáról nem győződhetett meg senki. Egy ilyen léptékü átállás első mérlegét minimum öt év után lehet tárgyszerüen megvonni, de az önkorrekció természetes lehetőségével is számolva a reális értékelés időtartama nem kevesebb, mint tíz év. Valójában annyi történt, hogy a jogszabály-rendszer immár teljes, az intézmények 
tanterveiket kidolgozták, az elengedhetetlen belső együttműködési rendjüket kialakították, felvettek és tanítanak tanár szakos hallgatókat.

Az egyedüli ténynek látszó ellenvetés, ami ebben a kritikai atmoszférában szinte perdöntő szerephez jutott: a természettudományos alapképzésből tanárnak jelentkezők alacsony száma. Ebből azonban nem a tanárképzés, hanem mindenekelött a természettudományos alapképzés válságos állapota olvasható ki, aminek kitágított kereteibe kellő felkészültség nélkül áramlanak be sokan, aminek hallgatói kvalitásaihoz nem idomították hozzá a követelményeket és módszereket, amelyben tehát 3 év alatt $15-17 \%$ végez, őket pedig a diszciplináris mesterszakok gazdag kínálata azonnal be is fogadja. Milyen módon tölthetné be az alapképzés épp a tanárképzés elötti előkészítő funkcióját? Ebben a vonatkozásban van még egy további, a bolognai elvektől szögesen eltérő „rendszerhibája”: formailag egységes, ám valójában kétféle alapdiplomát ad. Míg a fóáramban a hallgatók majd 180 kreditnyi diszciplináris felkészítést kapnak, addig a már az alapképzésben elkülönített „tanári” szakirányon csak 110 kreditnyit, lényegesen kevesebbet, és így tudásuk kevésbé piacképes, valamint nem jogosít a diszciplináris mesterszakra való felvételre. Azzal, hogy az alapképzést ily módon széthasítják, egy ígéretesebb és egy kevésbé ígéretes utat kínálnak fel. A hallgatót korán, gyakorlatilag első éves korában kényszerhelyzetbe hozzák, válasszon a lehetőségek között. Nem meglepő, hogy ők önként nem térnek le szakmailag az ígéretesebb útról (amelyen tavaly a kevésszámú végzett hallgató az utolsó szálig be is jutott a diszciplináris mesterképzésbe).

A minőség. Osztatlan az egyetértés, hogy a pedagógus a közoktatás meghatározó szereplője, aki a nagy demográfiai-kulturális változások idején nemzeti miszsziót teljesít. Az ő felkészítésének színvonalát szorgalmazza mindenki, ezt ígérte és ígéri a bolognai-rendszerü tanárképzés is, amikor egyetemi szinten egységesítette a tanárképzést, amely szakmai alapozásra épít gyakorlatorientált pedagógusképzést, kibővítve a mesterképzés kereteit.

Ezzel szemben idézik fel a gimnáziumi tudós tanárok példáit a világháború előtti időkből, valamint a Kádár-kor általános és középiskolai tanárképzésének rendezett kettősségét. A két modell azonban egymástól is gyökeresen eltér: Az előbbi a társadalmi elit nyolcosztályos gimnáziumban való oktatására készített fel, ez lehetőséget adott a „rendes egyetemi képzés” megtoldásával a tanárképző intézetben. Az utóbbi a kötelező általános, illetve a megszürt középiskola két ciklusára föiskolai, illetve egyetemi célzott pedagógusképzésben készített fel. Ez a bölcsészettudományi területen, a kutatói továbbhaladásra lehetőséget adott, a természettudományok terén azonban nem, itt a felsőfokú beiskolázástól kezdődően kontraszelektív volt: a kiválóak kutatói szakon tanultak, gyengébb pontszámmal tanári szakpárra lehetett bejutni az egyetemen, ennél is gyengébbel a föiskolán: ezen felvételkor elágazó utak között nem is volt átjárás.

Épp a minőség vonatkozásában a természettudományos tanárképzés osztatlan rendszerének visszaállitása sok jót nem ígér. Nincs okunk arra, hogy ezt a régi 
rendszert hatékonynak tekintsük, hiszen az abban kiképzett tanárok - talán pedagógiai eszköztelenségük miatt - bizonyosan hozzájárultak a természettudományos érdeklődés és tudás apadásához a közoktatásban. Ez egy beiskolázási kényszerekkel müködő, a föiskolák és egyetemek kettősségére épülő merev rendszer volt. A kontraszelektivitástól mindenképpen meg kellene óvni a természettudományos tanárképzést, márpedig több további javaslat is felmerült, amely a természettudományos tanárok korai elkülönítését és könnyített feltételekkel való kiképzését célozza ('́gy a mesterképzésbe való automatikus továbbhaladás, nyelvvizsga elengedése, a pedagógiai-pszichológiai stúdiumok rovására bővített keretekben speciálisan enyhített szakmai ismeretek átadása, emelt ösztöndíjjal csábítás) és így a minőség kiválása és kiválasztása ellen hat(hat).

A szak. A tanári mesterszak célirányosan a közoktatási szerepre készít fel. Nem titkolt szándék, hanem koncepcionális döntés eredményeképpen növekedett benne a korábbi egyetemi rendszerhez képest a pedagógiai-pszichológiai stúdiumok és a közoktatási gyakorlat aránya, és lett pedagógusképzés a besorolása. (Bármilyen fontos legyen is számára a biológia és a kémia, mégis orvost, bármilyen fontos a matematika és fizika, mégis mérnököt képezünk: a tudományok alkalmazásának egy-egy területére.) Mindemellett az alap- és mesterképzés közös nézetében az új rendszerben végző tanár szakmai tanulmányainak volumene egyik szakképzettségi területen meghaladja a korábbi egyetemi, a másik szakképzettségi területen eléri a korábbi főiskolai kredit-volument. A pedagógiai hangsúly egyértelmü, de ez nem sorvasztotta el tanárképzés diszciplináris összetevőjét.

A tanári mesterképzés a szakképzettségek sokaságát kínálja, ezek változatos kombinációjára ad lehetőséget, sem az oktatás, sem a közoktatási gyakorlat nem valósítható meg erős intézményi koordináció nélkül. Az elvi megfontolásokon túl az összehangolásnak ez a gyakorlati szükséglete is indokolja, hogy ne szakképzettségek szerint külön-külön, hanem egy egységként fogjuk fel a tanárszakot. Ez természetesen nem jár azzal, hogy a tanárképzésben kulcsfontosságú diszciplináris stúdiumok ne élveznének szakmai autonómiát, hogy az őket gondozó intézményrészek elvesztenék felelősségüket és az átháramlana a tanárszakot koordináló, képviselö, felügyelö testületre vagy személyre. A tanárszak oktatása jellegzetesen szakmaközi együttmüködés, elkerülhetetlenül az lenne akkor is, ha szakképzettségek szerint újra tanárszakok tucatjaira bomlana szét. Intézményesen garantált szakmaközi együttmüködés nélkül tanárképzés nem tud múködni.

Az ár. A bolognai reformmal kapcsolatban vissza-visszatér az a kritikai szempont, hogy bevezetése hajszolt volt. Története kétségtelenül hektikus, a FIDESZkormány vállalta fel miközben az intézményi integráció és a kreditrendszer bevezetése kötötte le erejét, az SZDSZ-es oktatási kormányzat korbáccsal és mézesmadzaggal átültette a gyakorlatba, az MSZP-s tárca lankadt ütemben hozta tető alá. A tanárképzés bolognai reformját élénk viták kísérték, ezek a CSEFT néven ismert kormányzati elképzelésekhez képest új irányt is szabtak számára. A magyar reform 
egyik alapvető hibája, hogy a képzési ciklusok összehangolása nem időben és nem átgondoltan ment végbe, sajátosan a tanárképzés hatókörzetére nem jellemző: a mélyreható változásoknak volt koncepciója, ami ütközések, kompromisszumok, szabályozási egyenetlenségek közepette, de lényegét tekintve érvényesült. Valamennyi érdekelt maradéktalan egyetértését valóban nem sikerült elérni, de együttmüködését igen, amit leginkább a HEFOP munkálatok végzése és az MRK által összefogott és előterjesztett szakmai-modul elöírások kidolgozása dokumentált.

Az ilyen - mindent felkavaró - átalakítás természetesen tapasztalati ellenőrzésre és óhatatlanul korrekcióra is szorul. Beválásának egyik alapvető kérdése, hogy a pedagógiai-pszichológiai tanulmányok sikerrel töltik-e be azt a megnövekedett szerepet, amelyet a tanárképzés új rendszerében kaptak, hogy a tanárok pedagógiai tudatosságát és hatékonyságát növeljék. Az egyik legfontosabb lehetőség, hogy a diszciplináris tanulmányok oldalán a szakmódszertanok a tekintetben domináns szerepet vívjanak ki maguknak, hogy meghatározzák és megoldani segítsék: a szaktudományos ismeretanyag tömkelegéből mit és hogyan közvetítsenek a jövő tanárai.

Az eddig befektetett munka elvész és az esélyek nem válnak valóra, ha a bevezetés állapotában lévő reform elakad, irányvételét elvitatják és visszafordul. Ez egy különösen nagysúlyú oktatáspolitikai döntés, amelynek meghozatalában biztos, hogy szaktudásra és nemzetközi átlátásra nagy szükség van. A pedagógusképzés módszeres (felül)vizsgálata nem egyszerü és népszerü kommentár, vagy valamely részérdek nyomatékos kifejtése, vagy tekintélyi vélemény, amely nagy nyomást gyakorol. Ez tudományos feladat, mégpedig - és ez a saját farkába harapó kígyó esete - az e tárgyban fogalomalkotásra, mérésre, történeti és nemzetközi keretben értelmezésre képes neveléstudomány feladata. Sokan, akik ezen s szakmán kívül állunk, hozzájárulhatunk szempontjainkkal a mérlegeléshez, de a hosszú távra meghatározó döntés szakszerü megalapozása bizonyára nem a mi feladatunk. Ugyanakkor a dilemmák tudományos vizsgálata nem lehet egyedül a magyar neveléstudomány belterjes ügye, hanem megkívánja a tágabb, európai tapasztalatgyüjtést és -kiértékelést, hiszen a bolognai-rendszer maga is európai lelemény, a meg-megingó közös perspektíva fontos alkotóeleme.

Tapasztalataim szerint, amelyeket a bölcsész-képesítési követelmények évtizedes kidolgozása és a most vitatott tanárképzési szisztéma átgondolása és vitatása során szereztem, a tanárképzés bevezetés alatt álló rendszerének felcserélése egy meröben újjal roppant nagy erőfeszítést igényel(ne): intézmények megmozgatását, pénzt, időt, szakértelmet, a manapság oly sokszor hiányolt hatásvizsgálatokat. Egy régivel való felváltása azonban teljesen reménytelen. 